\title{
Beneficial services of Glomalin and Arbuscular Mycorrhizal fungi in degraded soils in
}

\section{Brazil}

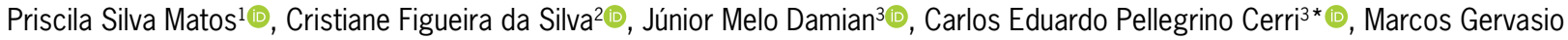 \\ Pereira ${ }^{1}$, Everaldo Zonta ${ }^{1}$
}

\author{
1 Universidade Federal Rural do Rio de Janeiro - Depto. de \\ Solos, BR 465, km 07 - 23897-000 - Seropédica, RJ - \\ Brasil. \\ ¿Universidade Federal Rural do Rio de Janeiro/Instituto de \\ Florestas, BR 465, km 07 - 23897-000 - Seropédica, RJ \\ - Brasil. \\ 3Universidade de São Paulo/ESALQ - Depto. de Ciência do \\ Solo, C.P. 09 - 13418-900 - Piracicaba, SP - Brasil. \\ *Corresponding author <cepcerri@usp.br>
}

Edited by: Paulo Cesar Sentelhas

Received March 03, 2021

Accepted May 30, 2021
ABSTRACT: Reducing soil degradation and its impacts on the environment have been one of the main challenges of the $21^{\text {st }}$ century, exacerbated by a direct link between increases in the human population and soil degradation that raises current and future food security concerns. Despite this, experiences worldwide reveal that degraded land restoration projects have either achieved little success or failed. Thus, understanding the underlying causes and devising appropriate restoration mechanisms is crucial. Soil amelioration using beneficial microorganisms, particularly arbuscular mycorrhizal fungi (AMF), is essential and pragmatic. Glomalin, a type of glycoprotein produced by arbuscular mycorrhizal fungi in the phylum Glomeromycota, contributes to the mitigation of soil degradation. Moreover, AMF and glomalin are highly correlated with other soil physico-chemical parameters and are sensitive to changes in the environment. As a result of this, they have been recommended for monitoring the recovery of degraded soil or stages of soil degradation. In this review, we discuss the role of AMF and glomalin in the restoration of degraded soils, including improvements to the soil structure and soil organic matter (SOM), microbial activity, reduction of fertility loss, bioremediation, and mitigation of the effects of drought and saline stress. We highlight the research gaps and discuss the prospects. This knowledge will improve our understanding of the ecological conduct of glomalin and AMF, stimulate future research, and be useful to sustainable restoration of degraded lands. Furthermore, we discussed the challenges and obstacles in the legislation and future perspectives on the production of inoculants based on AMF in Brazil.

Keywords: tropical soils, recovery, bibliometrics, environmental security, soil health

\section{Introduction}

Globally, reducing soil degradation and its impacts on the environment has been one of the main challenges of the $21^{\text {st }}$ century. Approximately $25 \%$ of the world's soil is severely degraded, and $50 \%$ is moderately degraded due to the aforementioned anthropogenic activities over the last few decades (Srivastava et al., 2019). Currently, Brazil is the second largest global supplier of food and agricultural products, and the country is poised to take the leadership in response to additional global demand (FAO, 2015). However, the agricultural expansion for the production of commodities is leading to severe erosion of arable land, nutrient loss, some overgrazing, environmental problems, and loss of biodiversity. According to predictions for the period 2015 to 2070 , Brazil will be substantially affected by soil erosion processes (Borrelli et al., 2020). Moreover, the manifold risks created by pollution, landslides, drought, and pandemics (e.g., COVID-19 in which recovery rates hypothetically correlate with healthy diet and thus soil quality, since soils with optimal nutrients, water and air produce healthy crops) are aggravated by a skyrocketing human population, lifestyle changes, and inappropriate use of technology (Landrigan et al., 2018).

Given this scenario, soil restoration has become a cause of concern for global leaders and has been an important theme of global environmental policies (Jacobs et al., 2015). In 2015, the UN concretized these global commitments by adopting the 2030 Sustainable Development Goals with one of the 17 targets (Target 15.3) dealing with soil restoration (UN, 2015). According to specialists, Brazil could meet that goal well before the year 2030, if the right strategies associated with the political effort are put into practice (CGEE, 2016). Herein, we propose inoculation with beneficial soil microbes such as AMF, which, when associated with glomalin, can provide a better restoration outcome for degraded lands.

In this review, we highlight and discuss aspects related to the beneficial services of AMF and glomalin in degraded soils, the mechanisms used by the inoculants of these fungi and glomalin in the recovery process of degraded areas, the challenges of the production of mycorrhizal inoculants in Brazil, as well as the use of these microbiological attributes as indicators of soil quality. The monitoring of AMF and glomalin in the soil is of fundamental importance to identifying the stage of soil degradation/recovery.

\section{Brief history of arbuscular mycorrhizal fungi and glomalin}

\section{Arbuscular mycorrhizal fungi}

Arbuscular mycorrhizal fungi (AMF) is considered the oldest and most widespread type of mycorrhiza (Smith and Read, 2010). There are AMF fossil records dating 
back to the Ordovician period, 460 million years ago (Redecker, 2000). These fossils suggest that they may have played a key role in the colonization of land by plants during that time (Remy et al., 1994). Therefore, they were crucial to the adapting the land plants to biotic and abiotic conditions and thus favor survival, growth, and development.

Mycorrhizal associations can be found in approximately $95 \%$ of all plant families and in $90 \%$ of agricultural plants (Smith and Read, 2010). AMF is classified as a member of the Mucoromyceta subkingdom and the phylum Glomeromycota phylum including three classes (Glomeromycetes, Archaeosporomycetes, and Paraglomeromycetes) (Tedersoo et al., 2018) (Figure 1). AMF belongs to 11 families, 25 genera, and nearly 300 species (Spatafora et al., 2016; Schüßler and Walker, 2019). The vast majority of members of the phylum Glomeromycota fungi are obligate symbionts, that is, they depend on the carbon substrates provided by their host plants to survive (Siddiqui and Pichtel, 2008). In return, the fungi improve the supply of water and nutrients, such as phosphate and nitrogen to the host plant through extraradical and intraradical hyphae, arbuscules, and the root apoplast interface (Parniske, 2008). Mycorrhizal symbiosis is elemental to plant productivity and diversity and it is rare to find a situation in which AMFs are not of significant ecological importance. Its beneficial effects on plant nutrition and growth, as well as on the relief of biotic and abiotic stress, have been widely described (Souza et al., 2017; Diagne et al., 2020; Li et al., 2020; Singh et al., 2020).

\section{Glomalin-related soil protein}

The first discoveries of the glomalin protein refer to studies with antibodies in AMF initiated by Dr. Sara Wright (USDA-ARS, Beltsville, EUA), in 1987 (Purin and Klauberg Filho, 2010). Wright et al. (1996) motivated by taxonomic difficulties in identifying $\mathrm{AMF}$, developed a specific antibody where AMF species showed reactivity, called MAb 32b11. Subsequently, it was demonstrated

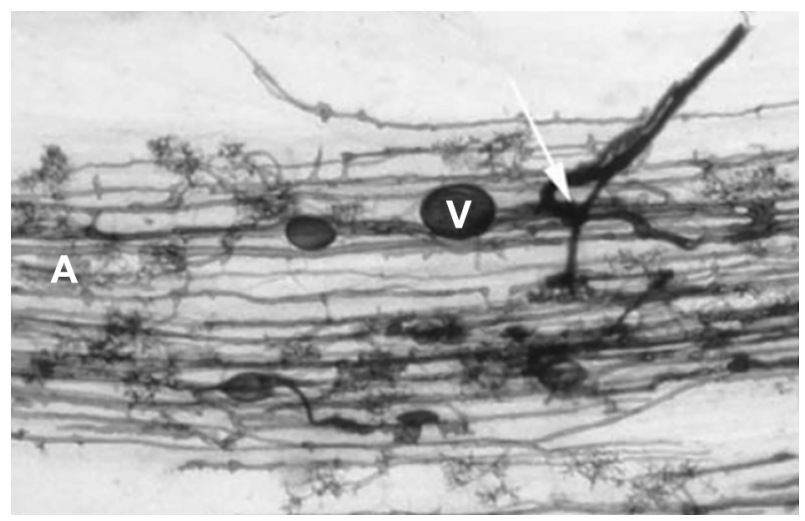

Figure 1 - Part of a colony of an AM fungus (Glomus sp.) with hyphae, arbuscules (A) and vesicles (V) growing from an entry point (arrow). Source: https://mycorrhizas.info/. that the MAb $32 b 11$ antigen in the mycelium of the fungus had a protein nature based on certain evidence: it was a protein proven by the Bradford method (Bradford, 1976) and had a positive result for binding lectin and its identification by capillary electrophoresis (Purin and Klauberg Filho, 2010). Wright et al. (1996) called this glycoprotein glomalin in reference to the Glomales taxon, to which the AMF belonged at the time. Another method of quantifying glomalin is through an immunological technique called ELISA. In this method, a monoclonal antibody MAb32b11 is used, produced from the spore macerate of Glomus intraradices injected into mice, recognizing the glomalin epitope only in $\mathrm{AMF}$, and not reacting with other soil fungi (Wright et al., 1996). However, to quantify the content of this protein, the most used method (Silva Filho et al., 2018; Liu et al., 2020) is the Bradford colorimetric tests proposed by Wright et al. (1996) and Wright and Upadhyaya (1998).

Wright and Upadhyaya (1998) developed methods of extracting protein from the soil and introduced terms for the classification of glomalin based on these methods. It is considered that the ease of extraction of the fractions reflects the period of contact between the soil and the protein since the association of the protein with the organomineral surfaces increases with time (Koide and Peoples, 2013). The term "easily extractable glomalin" (EEG) refers to the most recent fraction deposited in the soil, whose extraction is done with $20 \mathrm{mM}$ sodium citrate buffer and $\mathrm{pH} 7.0$ in a short autoclaving cycle $(30$ min at $121{ }^{\circ} \mathrm{C}$ ). In contrast, the term "total glomalin" (TG) designates the fraction most strongly fixed in soil particles, extracted with $50 \mathrm{mM}$ sodium citrate and $\mathrm{pH}$ 8.0 in successive autoclaving cycles $\left(60 \mathrm{~min}\right.$ at $\left.121^{\circ} \mathrm{C}\right)$. Rillig (2004) still made adaptations of the nomenclatures proposed by Wright and Upadhyaya (1998), maintaining the methods of extraction and quantification. The terms TG and EEG were renamed Bradford-reactive soil protein (BRSP) and Easily Extractable BRSP (EE-BRSP), respectively, based on the possibility of coextraction of other proteins and also mentioning the non-specificity of the Bradford assay for a single protein.

Afterwards, Koide and Peoples (2013) and Wu et al. (2014a) also proposed another nomenclature, divided the GRSP into two fractions, soil protein related to easily extractable glomalin (EE-GRSP) and glomalin-related soil protein difficult to extract (DE-GRSP). EE-GRSP is considered to be a newly synthesized and relatively more labile glomalin, while DE-GRSP is, comparatively, an older glomalin originated from EE-GRSP turnover, more difficult to extract and recalcitrant in soils. The total soil protein related to glomalin (T-GRSP) is the sum of EEGRSP and DE-GRSP. A recent study (Staunton et al., 2020) refutes this hypothesis that the easily extractable fraction is more recent compared to the total fraction, also highlighting that for complex surfaces such as soils, it is difficult to separate the effects of fixation which depends on the time that makes extraction less efficient, protein breakdown and loss of biological or biochemical 
activity (Hung et al., 2015). On the other hand, Staunton et al. (2020) support the fact that GRSP is not just the source of arbuscular mycorrhizal fungi. Thus, glomalin is the protein product of the gene, i.e., the protein produced by $A M F$, present in the walls of hyphae and spores. Soil fractions also referred to as "glomalin" summarily so far, will be referred from that point to as "glomalin-related soil protein" (GRSP), as proposed by Rillig (2004).

\section{Beneficial Services of AMFs and GRSP in degraded soils}

Soil degradation through erosion, compaction, loss of biological activity, acidification, salinization, or other processes can reduce soil quality by changing the soil attributes, such as soil biodiversity (e.g. AMF), GRSP content, soil organic matter, nutrient status, organic and labile carbon content, texture, available water-holding capacity, structure, maximum rooting depth, and $\mathrm{pH}$ (a measure of the acidity or alkalinity). Degraded soils capture less carbon from the atmosphere, interfering with climate change. By way of contrast, when managed sustainably, soil can play an essential role in reducing climate change through carbon sequestration (Figure 2). These edaphic perturbations limit the establishment of vegetation and soil restoration. Since the re-establishment of vegetation is a pioneering step for successfully recovering degraded lands, abiotic and biotic assistance is often provided to alleviate these plant stresses. For instance, inoculation with beneficial soil microbes in the rhizosphere is considered a vital option for improving the establishment of plant communities and to accelerate restoration of degraded terrestrial ecosystems (Chaudhary et al., 2020) (Figure 2).

In this context, several studies indicate an improvement in the growth and productivity of plants

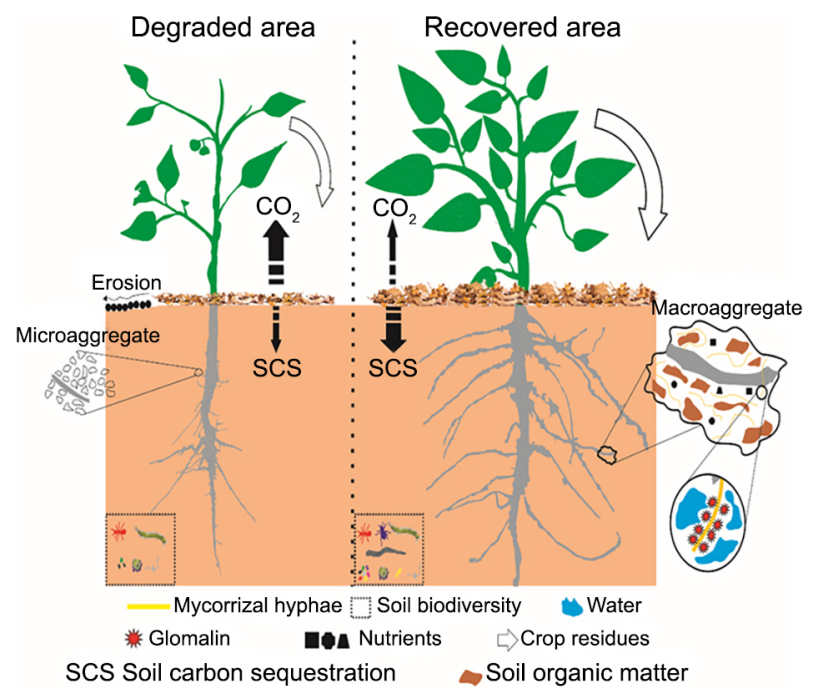

Figure 2 - Schematic representation of the main effects of AMFs and Glomalin on soil and plants. inoculated with AMF in degraded soils under field conditions (Birhane et al., 2014; Lin et al., 2015; Manaut et al., 2015). Moreover, studies indicate that mycorrhization can induce 19 to $26 \%$ more EE-GRSP and 13 to $20 \%$ more T-GRSP in the mycorrhizosphere than in the nonmycorrhizosphere after inoculation with AMF /Wu et al., 2014b), implying that inoculation with AMF could help in the production of endogenous GRSP fractions for later use. Wang et al. (2015) found that the fraction of EEGRSP was significantly higher, while the DE-GRSP and T-GRSP induced by mycorrhization were dependent on the AMF genotype since the hypha diameter, the hypha wall thickness, and its branching pattern collectively influenced the production of GRSP.

\section{Improvement of soil structure}

Soil disruption is one of the most important soil degradation indicators, mainly caused by the loss of soil organic matter (SOM), through intensive soil management practices and land-use changes (Wunder and Bodle, 2019). An essential service of AM fungi in natural as well as in degraded soils is the beneficial alteration of soil structure (Lehmann et al., 2017). AMF improves the soil structure both physically and chemically. Physically, soil particles are interconnected to each other through hyphae of arbuscular mycorrhizal fungi, promoting the stabilization of soil aggregates and increasing the absorption of soil nutrients by plants (Lehmann et al., 2017). Chemically, AMF releases glomalin, due to its stability and hydrophobicity, and works as an organic binder, helping to restore particulate material in the soil and promote the formation and improvement in the stability of aggregates (Rillig et al., 2017).

Strong positive correlation between GRSP and soil aggregate variables $\left(\mathrm{R}^{2}=0.41-0.78 ; p<0.05\right)$ has been found in diverse soil types and climatic conditions (Wright and Upadhyaya, 1998; Luna et al., 2016; Liu et al., 2020). It has been suggested that GRSP enhances soil aggregate stability by improving the aggregate bond energy, particularly for macroaggregates (Ji et al., 2019). Moreover, an increase in the GRSP concentration in soil improved other soil physical properties, such as decreased bulk density and an increase in soil porosity, moisture content, and water-holding capacity (Gispert et al., 2013; Singh et al., 2016). Nobre et al. (2015) in a study on aggregation, GRSP and SOC in Chapada do Araripe (Ceará), found positive correlation between the carbon levels (TOC and POC), the GRSP fractions (EE-GRSP and GRSP) and between GRSP and aggregate stability, showing that the protein produced by AMF directly influences carbon concentrations and the stability of aggregates in the Chapada do Araripe soil. A similar result was found by Silva Filho et al. (2018), who found positive correlation between GRSP fractions and aggregate stability. In addition to this direct effect on soil structure, GRSP reduces soil erosion and improves soil thickness by forming soil aggregates (Gispert et al., 2013). 


\section{Improvement of soil organic matter (SOM)}

The restoration of degraded lands also increases the soil organic matter (SOM), which is widely accepted as a solution to multiple soil degradation problems and global climate change (Singh et al., 2019). For instance, "4 per 1000 Initiative: Soils for Food Security and Climate" was launched at COP21, with a global aspirational goal to increase SOC stock at an annual rate of $0.4 \%$ per year in soils of all anthropogenic and natural land uses (Soussana et al., 2019).

Total GRSP concentrations in soil certainly have a close link to total SOM concentrations (Li et al., 2020). Recent studies have shown that GRSP was the most important source of C in SOM-C (SOC) (Single et al., 2017; Whang et al., 2018; Zhang et al., 2017; Kumar et al., 2018). It has been estimated that GRSP contains approximately $37 \% \mathrm{C}$ and is responsible for $4-5 \%$ of the total soil C (Rillig et al., 2001). The chemical structure of GRSP was revealed by the solid-state ${ }^{13} \mathrm{C}$ cross polarization magic angle spinning method (Zhang et al., 2017). The authors, found a higher proportion of aromatic $\mathrm{C}$ ( $\sim 30 \%$ of the total content) and carboxyl C ( $\sim 40 \%$ of total content), alkyl C ( 30\%) and O-alkyl C ( 50\%), and, further, calculated the recalcitrance index (|alkyl C + aromatic $\mathrm{C}) /(\mathrm{O}$-alkyl $\mathrm{C}+$ carboxyl $\mathrm{C}) /$, and found a significantly higher recalcitrance index for GRSP (mean range $73-102 \%$ ) versus total SOC (mean range 43-61 \%).

The persistence of GRSP in the soil is estimated between 6 and 42 years in tropical soils, greater than that observed for mycelium, which is estimated to be a few days (Rillig et al., 2001). Steinberg and Rillig (2003), evaluating percentages of decomposition, found that the concentrations of GRSP decreased by $25 \%$ in 150 days, while the mycelium of the AMF decreased by $60 \%$. Recent findings indicate that the greater contribution of GRSP to SOC in deep soils is related to the greater stability of SOC (Whang et al., 2018). Underground SOM is enriched with $\mathrm{C}$ compounds derived from microorganisms and can be depleted in energy-rich plant material compared to the top layer of SOM (Rillig et al., 2001; Rillig et al., 2003). Consequently, the increased fraction of $\mathrm{C}$ derived from GRSP for SOC with increasing sampling depth could provide new evidence that $\mathrm{C}$ derived from microbial biomass, especially that of C-AMF, promoted the accumulation of SOC in the subsoil. Therefore, actively improving the GRSP content in the soil can be a strategy to improve the storage of $\mathrm{C}$, and consequently, SOM in the soil. Currently, the viable alternative is to promote the growth of AMF that will subsequently produce glomalin in situ, as there is no other known source/mechanism of glomalin production (Singh et al., 2020).

\section{Improvement in soil fertility}

Depletion of soil nutrients is one of the main indicators of soil degradation, usually attributable to accelerated conventional cultivation practices to meet the demand for food and other agricultural products, but can also be caused by the lack of soil fertility management in pastures.

Several studies on GRSP have provided important data on its role to cope with this soil degradation problem (Singh et al., 2016; Wang et al., 2018; Zhang et al., 2017). The microbial decomposition of GRSP releases a range of nutrients such as carbon (30-40\%), nitrogen (3-5 \%), phosphorus (3-4 \%), iron (1-9\%) and other nutrients (1-2 \%) ( $\mathrm{S}, \mathrm{K}, \mathrm{Ca}, \mathrm{Mg}, \mathrm{Zn}$, and $\mathrm{Cu})$ in the soil for plant uptake (Singh et al., 2016; Wang et al., 2018; Zhang et al., 2017). A number of studies have shown the direct effects of increasing GRSP concentration on plant growth /Garcia et al., 2019; Muchane et al., 2018). Moreover, glomalin can indirectly enhance plant growth through improvements in AMF activity in the soil (Singh et al., 2020). Many studies have shown that inoculation of AMF heavily increased the concentration of rhizosphere GRSP (Xie et al., 2013; Yang et al., 2017; He et al., 2020). Furthermore, the effect of AMF on increased absorption and reduced leaching of nutrients has also been documented (Cavagnaro et al., 2015; Querejeta, 2017).

AMF plays a crucial role in tropical soils, especially in regard to supporting the phosphorus absorption process, since in these soils the phosphorus loss is high due to the fixation process (Fontes and Alleoni, 2006). Through extensive networks of extraradical mycelium, AMF accesses soil mineral nutrients inaccessible to their host plant, including nutrient pools beyond the root depletion zone (Smith and Read, 2010), and may also mineralize organic P sources (Koide and Kabir, 2000). Mycorrhizal symbiosis can also increase the absorption of $\mathrm{N}$ and its immobilization in fungal biomass, significantly reducing the loss of this nutrient in agricultural or natural ecosystems (Cavagnaro et al., 2015). Such absorption and immobilization, especially of ammonium, reduces nitrification and, consequently, loss by leaching, since nitrate is extremely mobile in the soil. In addition, there is a reduction in the production of nitrous oxide (Storer et al., 2018), a greenhouse gas capable of promoting heating approximately 300 times higher than that of $\mathrm{CO}_{2}$ (IPCC, 2001). It is important to note that the effect of AMF as a soil conditioner has been well documented. However, there is still a gap in the research on the role of glomalin in increasing nutrients, and also as prebiotics for plants. Further studies should be conducted in this area to fill in this gap in the research.

\section{Improvement in microbial activity}

The positive correlation between GRSP and microbial activity has been documented in previous studies. Since AMF is a major producer of glomalin, a higher GRSP level in the soil indicates higher soil mycorrhizal fungal activity. Therefore, GRSP is an indicator of higher microbial activity since AMF body parts (extraradical hyphae and spores) constitute $20-30 \%$ of soil microbial biomass, and the contribution of AMF in total soil microbial respiration 
is substantial (up to $25 \%$ ) (Zhang et al., 2016). Moreover, positive correlation between GRSP and microbial biomass $\mathrm{C}$ and microbial respiration has been found in multiple soil environments (Gispert et al., 2013; Wang et al., 2018). GRSP can also increase microbial catabolic functions (i.e., the release of extracellular enzymes) as it is a microbial decomposition substrate (Singh et al., 2020). Soil extracellular enzyme activities, such as b-glucosidase, phosphatase, fluorescence diacetate, and dehydrogenase, showed positive correlation with the GRSP (Wu et al., 2015). For example, in a microcosm experiment, Wu et al. (2015) found increasing GRSP concentration increases b-glucosidase, catalase, peroxidase, and phosphatase enzyme activities in soil. Similarly, in a free-air $\mathrm{CO}_{2}$ enrichment experiment with tree saplings (Tectona grandis and Butea monosperma), Singh et al. (2019) reported positive correlation between GRSP and acid phosphatase, b-glucosidase, dehydrogenase, and fluorescein diacetate enzyme activities.

\section{Bioremediation}

Soil degradation problems are not only linked to agriculture intensification and over-exploitation of nutrients (e.g., carbon, nitrogen, and phosphorus) of soil but are also caused by multiple pollutants (e.g., heavy metals, polycyclic aromatic hydrocarbons, nanomaterials, etc.) from various anthropogenic source discharge on land (Wu et al., 2020). The AMF plays a crucial role in areas degraded or polluted by heavy metals, helping plants survive in such stressful conditions (Hildebrandt et al., 2007; Conversa et al., 2019; Song et al., 2020). The mechanism used by AMF to promote heavy metal remediation can be activated through hyphal "metal binding", which reduces the bioavailability of elements, such as $\mathrm{Cu}, \mathrm{Pb}, \mathrm{Co}, \mathrm{Cd}$, and $\mathrm{Zn}$ (Audet and Charest, 2007). They also expressed certain metal transporters that could be involved in heavy metal tolerance in plants inoculated by AMF (Diagne et al., 2020). For instance, $\mathrm{Zn}$ transporters, such as GintZnT1 from $R$. irregularis (González-Guerrero et al., 2016). Several putative gene codings for $\mathrm{Cu}, \mathrm{Fe}$, and $\mathrm{Zn}$ transporters were identified in AMF (Tamayo et al., 2014).

Glomalins also play a key role as active agents in providing tolerance to heavy metals. According to Purin and Rillig (2007), one of the functions of glomalin in AMF is complex protein-metal formation. The findings suggest that the glomalin proteins' assistance in wall binding has additional functions other than that of cytoplasmic heat shock proteins, which further influence the AMF and plants to withstand metal stress. Studies conducted by Chern et al. (2007) revealed the contribution of GRSP in decrementing the phytotoxicity induced by $\mathrm{Cd}, \mathrm{Cu}$, and $\mathrm{Zn}$. In soils contaminated with heavy metals, Gonzalez-Chavez et al. (2004) found that the GRSP proteins can quench up to $80 \mathrm{mg}$ of $\mathrm{Cd}$, of $\mathrm{Pb}$, and $4300 \mathrm{mg} \mathrm{kg}^{-1}$ of $\mathrm{Cu}$.
Aluminium (Al) toxicity is the main factor limiting plant growth in acid soils that are widely distributed throughout tropical and subtropical regions (Sade et al., 2016). Management of arbuscular mycorrhizal fungi $(\mathrm{AMF})$ is considered an important factor in the enhancement of tolerance to potentially toxic elements such as Al (Seguel et al., 2017; Cornejo et al., 2017). A number of studies have revealed several possible mechanisms of $\mathrm{Al}$ tolerance induced by $\mathrm{AM}$ fungi in higher plants, including that (a) AM fungi improve the uptake of phosphorus $(\mathrm{P})$ and other nutrients in their host plants through Al-P interaction in colonized roots, which is critical to the maintainance of plant growth under $\mathrm{Al}$ stress (Seguel et al., 2013); (b) AM fungi stimulate the processing of carbon in roots through the citric acid cycle to enhance the exudation of organic acids, which chelates $\mathrm{Al}^{3+}$ in the rhizosphere (Seguel et al., 2013); (c) GRSP produced by AM fungi has the capacity to sequester $\mathrm{Al}^{3+}$ in the rhizosphere (Seguel et al., 2013); (d) AM fungal structures such as spores and hyphae have the capacity to bind Al directly or build an enlarged mycorrhizosphere in which $\mathrm{Al}$ is detoxified (Joner et al., 2000; Göhre and Paszkowski, 2006). According to Aguilera et al. (2018), AMF has the potential to alleviate Al phytotoxicity through a chemical barrier in which glomalin sequesters Al beyond the root surface, which seems to be an important trait of AMF and would be used for developing management strategies of acidic soils with high Al levels.

\section{Reducing the effects of drought and saline stress}

Drought and salinity are severe and extensive soil stressors, intensified by climatic change, that produce land degradation, whose negative effects on plant growth may be mitigated by the action of AMF and GRSP (Elhindi et al., 2017; Chi et al., 2018; Ji et al., 2019). There are different mechanisms through which AMFs reduce the adverse effects of abiotic stresses. Among these mechanisms are increased water use efficiency, improved stomatal conductance and increased activity of antioxidant enzymes to reduce peroxidative damage (Duc et al., 2018; Li et al., 2019). Moreover, under osmotic stress, aquaporins (AQPs) are important in regulating the water flow of plants. Aroca et al. (2009) cloned the first aquaporin from an AMF (GintAQP1). They found that GintAQP1 expression was upregulated in parts of the mycelium that were not osmotically stressed by $\mathrm{NaCl}$ while other parts of the mycelium were stressed. This suggests a possible communication between the non-stressed and the stressed mycelium. Two functional genes have been characterized, GintAQPF1 and GintAQPF2, which code for AQPs present in the AMF Rhizophagus intraradices (Li et al., 2013a), that are overexpressed under osmotic stress conditions, helping the fungus to tolerate stress and potentially increasing the water supply to a host plant under these conditions (Li et al., 2013b). 
AMF have been consistently shown to improve nutrient uptake and maintain ionic homeostasis in saline soils (Heikham et al., 2019). AMF reduces the translocation of $\mathrm{Na}^{+}$ions to plant tissues, preventing their concentration from reaching toxic levels. This is due to the ability to retain these ions in structures such as the intraradical mycelium and vesicles, by accumulating ions in their vacuoles (Mardukhi et al., 2011). Moreover, studies with Rhizophagus intraradices have shown their ability to selectively absorb mineral nutrients such as $\mathrm{K}^{+}, \mathrm{Mg}^{2+}$ and $\mathrm{Ca}^{2+}$, preventing the entry of $\mathrm{Na}^{+}$in the mycorrhizal structures, maintaining high ratios of $\mathrm{K}^{+}$: $\mathrm{Na}^{+}, \mathrm{Ca}^{2+}: \mathrm{Na}^{+}$and $\mathrm{Mg}^{2+}: \mathrm{Na}^{+}$(Mardukhi et al., 2011).

In addition, Garcia et al. (2019) showed that, in the presence of salinity, soil inoculated with AMF increases the content of GRSP, which has numerous beneficial effects on the restoration of soil health. Abiotic stresses, as drought and salinity, has been reported to increase GRSP contents (Hammer and Rillig, 2011; Krishnamoorthy et al., 2014; Zou et al., 2014; Garcia et al., 2019). A study carried out by Chi et al. (2018) showed that exogenously applied GRSP could strongly stimulate root morphology and plant growth under drought stress. GRSP can also modulate the phytohormones especially auxin (IAA), abscisic acid (ABA), and methyl jasmonate (MeJA) concentrations under drought stress. Therefore, the exogenous treatment of GRSPs is suggested as a plant growth regulator for improving drought tolerance (Chi et al., 2018). Wu et al. (2008) showed that inoculation with Funneliformis mosseae and Diversispora versiformis increased the production of GRSP under water deficit, by promoting the stability of soil aggregates. In this context, Nichols (2008) further proposed that GRSP can act as a coating on fungal hyphae to prevent water loss, and by the formation of a hydrophobic layer in the aggregate topsoil of the soil to reduce water loss in soil aggregates under drought stress. Later studies by Wang et al. (2015) showed the strong positive relation of exogenous EE-GRSP to soil aggregation, rhizospheric enzyme activities and plant growth. Ji et al. (2019) found that AMF and GRSP contribute to the formation and stability of soil water-stable macroaggregates even under drought stress conditions.

\section{Advances and perspectives: production of AMF inoculants}

Many studies have described the importance of inoculation of AMF for development in agriculture, as well as for reforestation programs in degraded areas (Birhane et al., 2014; Lin et al., 2015; Souza et al., 2017). However, obligate biotrophic hinders the production of arbuscular mycorrhizal inoculants since the fungus requires metabolically active roots to complete its life cycle (Moreira and Siqueira, 2006). Consequently, they cannot be multiplied separately in a defined culture medium (Douds Jr. et al., 2006). Because of this, it is very difficult to develop low-cost methods for high-quality inocula production on a large scale (IJdo et al., 2011).
Thus, these fungi are usually multiplied in host plants in culture pots, aeroponic cultivation, hydroponics, or in vitro culture with genetically transformed roots (IJdo et al., 2011). These processes are carried out under controlled or semi-controlled conditions, such as greenhouses or growth chambers (IJdo et al., 2011).

The richness of AMF in the production of inoculants is considered to improve their effectiveness. The plant's response is substantially less when inoculated with unique species of AMF and the response increases when several species of fungi are used for soil inoculants (Hoeksema et al., 2010). Inoculation with AMF should be carried out whenever possible, in order to guarantee fast and efficient colonization. It is essential in situations where the presence of native AMF propagules is low or nonexistent or in communities with low diversity of AMF (Souza et al., 2017). It is important to highlight the potential negative consequences of introducing nonnative soil organisms to restoration sites since these introductions may not be reversible. Commercially produced AMF inoculants represent a small genetic pool of fungi selected to be at once generalists and aggressive colonizers. These traits have the potential to threaten local AMF communities, which may not be resistant to alien introductions (Hart et al., 2017). Evidence has been accumulating indicating that non-native commercial fungi are not beneficial to restoration (Middleton et al., 2015; Koziol et al., 2018).

A number of authors suggest that as a recovery strategy for areas degraded by mining, AMF inoculation may be more suitable only under the few conditions where the native inoculum has disappeared or existed in small quantities (Brundrett and Abbott, 2002), and it would be better to focus on managing the local AMF community rather than inoculation (Koide and Mosse, 2004; Souza et al., 2017). Although inoculation may improve growth during the first few years, uninoculated plants may eventually become colonized by resident AMF (Estaún et al., 2003) and perform as good or better than inoculated plants (Middleton et al., 2015).

The production of aseptic inoculum has been achieved through in vitro cultivation of the fungus in association with root cultures transformed by Agrobacterium rhizogenes. Other production methods generally do not guarantee the production of inoculants free from other microorganisms, thus making it difficult to register arbuscular mycorrhizal inoculants in Brazil. Production in greenhouses, where fungus is cultivated with species of host plants, usually grasses, is a relatively cheap and efficient method, and is the most used by research institutions and universities in Brazil, beit for the production of inoculum or for maintaining crop collection (Souza et al., 2017).

Production of aeroponics systems has also been developed by Brazil's research institutions (Santana et al., 2014). Despite the high technological level developed in Brazilian research institutions, the national inoculant industry has not yet incorporated the technologies. 
Despite the high technological level developed in Brazilian research institutions, the national inoculant industry has not yet incorporated the technologies. Certain products are obtained from the in vitro cultivation of the fungus associated with root crops. Nevertheless, in the majority of cases, inoculants produced in systems with plants are also commercialized, either in cultivation pots with different substrates or through more sophisticated techniques, such as hydroponics and aeroponics (Ijdo et al., 2011).

Another method that is gaining notoriety is the production of inoculum under field conditions, known as the on farm method (Douds Jr. et al., 2006). In this process, the soil collected in the farm is used as inoculum. The soil containing propagules of AMF is inoculated on a substrate based on vermiculite and an organic compound and is cultivated with grasses, such as corn, sorghum, and millet as well as legumes. Subsequently, after a period of four to six months, the substrate containing multiplied spores is used as an inoculum (Souza et al., 2017). This technique is a low-cost alternative for farmers; moreover, they can produce seedlings already mycorrhizal with this benefit enhancing the establishment of seedlings in the field.

In Brazil, present legislation for registering microbial inoculants for agriculture makes it challenging to produce and trade official products containing AMF. Given this scenario, changes to, and/or the creation of laws are necessary to expand the limited market for inoculants of AMFs currently in existence in Brazil (Saggin Júnior, 2019). These modifications will allow norms for inoculants and agronomic tests to be directed to AMFs and the presence of multiple species in the inoculants. In addition to allowing for the sale of soil conditioners that contain AMF propagules, taking into account the supply of AMF species that cannot be multiplied under axenic conditions AMFs remain important to forest production. Moreover, the proposed changes will facilitate the registering of AMF inoculants produced under axenic conditions, and are not subject to specific requirements for bacterial inoculants. Despite these challenges, in 2018 the first mycorrhizal inoculant was registered with the Ministry of Agriculture, Livestock and Supply (MAPA) for commercial use, and as an application for soybean and corn seed treatment (as well as for wheat, rice, barley, oats and beans).

\section{Gomalin and AMF as soil indicators in degraded areas}

Given the relevance of AMF and GRSP for the restoration of degraded soils, it is recommended that they are assessed in studies of anthropogenic impacts and monitoring programs (Islas et al., 2016; Silva et al., 2017; Pereira et al., 2018; Šarapatka et al., 2019). Since both AMF and GRSP have positive correlation with the main edaphic attributes used for soil quality assessments (Silva et al., 2017; Šarapatka et al., 2019); i.e., the greater the diversity of AMF species and the GRSP content, the better the soil quality (Silva et al., 2017; Pereira et al., 2018). Moreover, they are susceptible to land-use change (Silva Filho et al., 2018; Silva et al., 2016; Nogueira et al., 2016) and management practices (Islas et al., 2016).

Given the importance of GRSP as soil health components (Pereira et al., 2018; Silva Filho et al., 2018) research into this variable has been growing worldwide (Figure 3A and B). In Brazil, there was a peak in studies on this topic in 2012 and 2016, with a decrease in subsequent years. However, research associating GRSP, AMF, and restoration of degraded areas are scarce in Brazil (Figure 3C, D and Table 1), limited to the southeast and northeast regions, under the Atlantic Forest and Caatinga biomes (Table 1). Our bibliographic research reveals that there is a scarcity of studies on the topic in areas such as the Amazon and Cerrado biomes, for example, where a large part of the soils is at some level of degradation, either by intensive use of the soil, or by natural events such as forest fires. In addition, most research evaluates the behavior of AMF and GRSP under different techniques for recovering degraded areas (Table 1). There is little research on using inoculated species in degraded areas.

\section{Final Remarks and Future Perspectives}

Soil restoration is essential to providing food to people, strengthening and sustaining ecosystem services. The soil is non-renewable on a human timescale (decades), and sustainable alternatives of soil restoration such as the use of AMF and GRSP are vital to guaranteeing goods for future generations. Recognizing that this study addresses the benefits that AMFs associated with GRSP can improve soil quality in terms of soil structure, increase SOM, reduce fertility losses, and increase microbial activity thereby remedying soils contaminated by heavy metals. The adoption of these technologies to restore degraded soils is reflected in increases in production, which are so important to ensuring that they continue to provide their wide range of services for the soon to be 9.8 billion inhabitants of our planet. Moreover, they can assist in the mitigation of global warming through a potential increase in soil carbon sequestration.

Despite biotechnological advances related to the production of AMF in Brazil, production costs and bureaucracy established by MAPA have still been limiting factors on production in Brazil. It is therefore necessary that changes and/or the introduction of new laws to facilitate the commercialization of these products and enable the use of this technology for Brazil to be able to comply with international agreements (Paris Agreement) and achieve more ambitious goals such as the sustainable development objectives proposed in the Agenda for 2030. Brazil has a significant amount of degraded areas that, if they were recovered and incorporated into the production system, would eliminate the need to clear new land to support increased agricultural and livestock production. 
Table 1 - List of studies evaluating the use of AMFs and glomalin as indicators for assessing the recovery of degraded areas in Brazil.

\begin{tabular}{|c|c|c|c|c|c|}
\hline Year & Authors & Local & Biome & Study areas & Main results \\
\hline 2010 & Mergulhão et al., 2010 & Araripina-PE & Caatinga & $\begin{array}{l}\text {-Native forest } \\
\text {-Degraded area surrounding the mine } \\
\text { - Waste deposit area } \\
\text {-Interface between the waste deposit and } \\
\text { mining degraded area }\end{array}$ & $\begin{array}{l}\text { The EEG can be used as an indicator of } \\
\text { differences between preserved "caatinga" } \\
\text { versus areas impacted by gypsum mining }\end{array}$ \\
\hline 2012 & Carneiro et al., 2012 & Gilbués-PI & Caatinga & $\begin{array}{l}\text {-Area under recovery with plant legumes } \\
\text { and forage grasses } \\
\text {-Area degraded with erosion } \\
\text {-Area with initial degradation process } \\
\text {-Native forest }\end{array}$ & $\begin{array}{l}\text { The cultivation of grasses and forage } \\
\text { legumes associated with erosion control } \\
\text { practices increases number of AMF } \\
\text { community in degraded areas }\end{array}$ \\
\hline 2012 & Silva et al., 2012 & $\begin{array}{l}\text { Campos dos } \\
\text { Goytacazes-RJ }\end{array}$ & Atlantic Forest & $\begin{array}{l}\text {-Pure planting of Eucalyptus camaldulensis } \\
\text {-Pure planting of Acacia mangium } \\
\text {-Consortium of Eucalyptus camaldulensis } \\
\text { + Acacia mangium } \\
\text {-Degraded area with vegetation } \\
\text { spontaneous }\end{array}$ & $\begin{array}{l}\text {-The diversity of AMF spores, T-GRSP and } \\
\text { EE-GRSP increases with the revegetation } \\
\text { of the clay pit; } \\
\text {-Consortium of Eucalyptus camaldulensis } \\
+ \text { Acacia mangium promotes an increase } \\
\text { in the diversity of AMF, in relation to } \\
\text { eucalyptus monoculture. }\end{array}$ \\
\hline
\end{tabular}

-Higher diversity of AMF in NT than others; -AMF species richness was correlated with the gradient of environmental restoration;

-Native forest area (NT)

2013 Vasconcellos et al., 2013 São Paulo
-5 years after revegetation

-10 years after revegetation

-20 years after revegetation
- EE-GRSP and T-GRSP positively related to total carbon, nitrogen and enzymatic activity, but negatively related to bulk density.

-Glomalin and AMF may be used as indicators of soil quality in the Atlantic forest.

\begin{tabular}{|c|c|c|c|c|c|}
\hline 2014 & Silva et al., 2014 & $\begin{array}{l}\text { Campos dos } \\
\text { Goytacazes-RJ }\end{array}$ & Atlantic forest & $\begin{array}{l}\text {-Soil degraded by clay extraction with } \\
\text { spontaneous vegetation } \\
\text {-Pure plantings of Sesbania virgata } \\
\text {-Integrated system with Eucalyptus } \\
\text { camaldulensis and Acacia mangium }\end{array}$ & $\begin{array}{l}\text { The revegetation of the clay extraction } \\
\text { pit with Sesbania virgata, in pure or } \\
\text { intercropped plantations reduces the } \\
\text { amount of soil protein related to glomalin }\end{array}$ \\
\hline 2015 & Silva et al., 2015 & Mataraca-PB & Atlantic Forest & -Natural and revegetated area & $\begin{array}{l}\text { Revegetated areas areas had a higher } \\
\text { species richness of AMF than Natural } \\
\text { areas. }\end{array}$ \\
\hline 2016 & Nogueira et al., 2016 & Passa Vinte-MG & Atlantic Forest & $\begin{array}{l}\text {-Secondary Forest } \\
\text {-Natural Pasture } \\
\text {-Natural Regeneration areas }\end{array}$ & $\begin{array}{l}\text { The conversion of native forest into } \\
\text { pasture reduced T-GRSP and EE-GRSP. }\end{array}$ \\
\hline 2017 & Silva et al., 2017 & Pinheiral-RJ & Atlantic Forest & $\begin{array}{l}\text {-Secondary forest early stage } \\
\text {-Secondary forest medium stage } \\
\text {-Secondary forest advanced stage } \\
\text {-Pasture } \\
\text {-Perennial agriculture } \\
\text {-Annual crops }\end{array}$ & $\begin{array}{l}\text { The conversion of forest to agriculture } \\
\text { reduces the soil protein content related to } \\
\text { glomalin. }\end{array}$ \\
\hline 2018 & Pereira et al., 2018 & $\begin{array}{l}\text { Contendas do } \\
\text { Sincorá-BA }\end{array}$ & Caatinga & $\begin{array}{l}\text { Three types of forest management } \\
\text {-Clear-cutting } \\
\text {-Selective logging based on diameter } \\
\text {-Selective logging based on species } \\
\text {-Control area (Native forest) }\end{array}$ & $\begin{array}{l}\text {-The AMF community is sensitive to } \\
\text { changes caused by forest management. } \\
\text {-The different managements cause } \\
\text { changes in the AMF community. } \\
\text {-The AMF community can recover over } \\
\text { time. }\end{array}$ \\
\hline 2018 & Silva Filho et al., 2018 & Sobral-CE & Caatinga & $\begin{array}{l}\text {-Overgrazing } \\
\text {-Exclusion } \\
\text {-Native Forest }\end{array}$ & $\begin{array}{l}\text { The contents of GRSPEE and GRSPT of the } \\
\text { native forest were higher than those found } \\
\text { in the areas of exclusion and overgrazing }\end{array}$ \\
\hline 2019 & Silva et al., 2019 & $\begin{array}{l}\text { Assú-RN } \\
\text { Pendências-RN } \\
\text { Carnaubais-RN }\end{array}$ & Caatinga & $\begin{array}{l}\text {-Gravel mine J1-P } \\
\text {-Gravel mine J2-P } \\
\text {-Umpjack base PB-P } \\
\text {-Waste disposal area WDA-P } \\
\text {-Native vegetation }\end{array}$ & $\begin{array}{l}\text { AMF presented lower densities in the } \\
\text { evaluated areas when compared to those } \\
\text { in the adjacent native vegetation areas. }\end{array}$ \\
\hline 2020 & Weber et al., 2020 & Acaraú-CE & Atlantic Forest & $\begin{array}{l}\text {-Forest planting with native tree species } \\
\text {-control area (non-forested area) }\end{array}$ & $\begin{array}{l}\text { The cultivation of these species for } 6 \\
\text { years increases glomalin-related soil } \\
\text { protein. }\end{array}$ \\
\hline
\end{tabular}



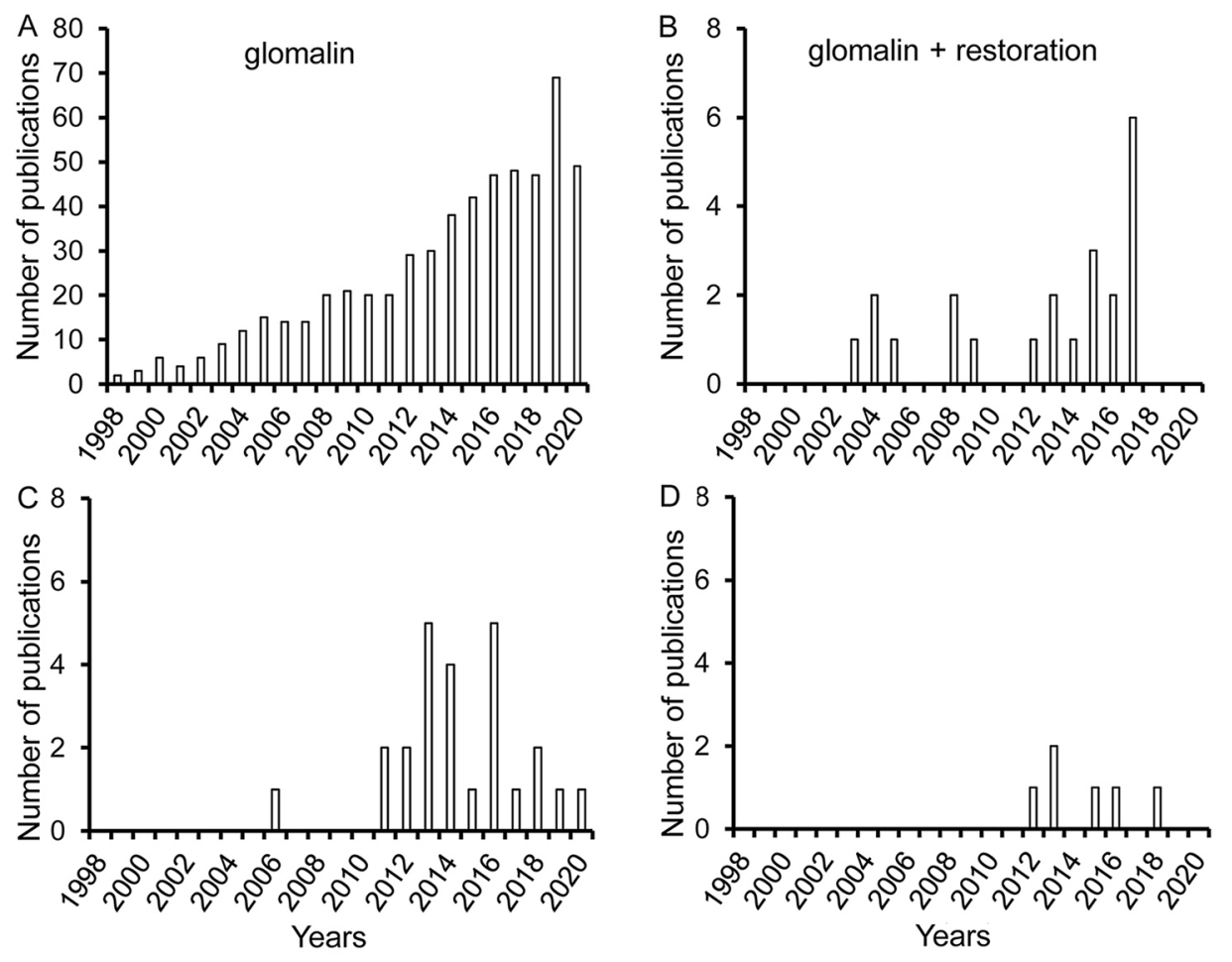

Figure 3 - Survey of the number of studies in the Web of Science database about glomalin and restoration of degraded areas in the world (A and $\mathrm{B}$ ) and in Brazil (C and D).

\section{Authors' Contributions}

Conceptualization: Silva, C.F.; Matos, P.S. Data acquisition: Damian, J.M.; Matos, P.S. Writing and editing: Matos, P.S.; Silva, C.F.; Cerri, C.E.P.; Damian, J.M.; Zonta, E.; Pereira, M.G.

\section{References}

Aguilera, P.; Larsen, J.; Borie, F.; Berríos, D.; Tapia, C.; Cornejo, P. 2018. New evidences on the contribution of arbuscular mycorrhizal fungi inducing $\mathrm{Al}$ tolerance in wheat. Rhizosphere 5: 43-50.

Audet, P.; Charest, C. 2007. Heavy metal phytoremediation from a meta-analytical perspective. Environmental Pollution 147: 231-237.

Aroca, R.; Bago, A.; Sutka, M.; Paz, J.A.; Cano, C.; Amodeo, G.; Ruiz-Lozano, J.M. 2009. Expression analysis of the first arbuscular mycorrhizal fungi aquaporin described reveals concerted gene expression between salt-stressed and nonstressed mycelium. About Molecular Plant-Microbe Interactions 22: 1169-78.

Birhane, E.; Sterck, F.J.; Bongers, F.; Kuyper, T.W. 2014. Arbuscular mycorrhizal impacts on competitive interactions between Acacia etbaica and Boswellia papyrifera seedlings under drought stress. Journal of Plant Ecology 1: 298-308.

Borrelli, P.; Robinson, D.A.; Panagos, P.; Lugato, E.; Yang, J.E.; Alewell, C.; Ballabio, C. 2020. Land use and climate change impacts on global soil erosion by water (2015-2070). Proceedings of the National Academy of Sciences 117: 21994-22001.
Bradford, M.M. 1976. A rapid and sensitive method for the quantitation of microgram quantities of protein utilizing the principle of protein-dye binding. Analytical Biochemistry 72: 248-254.

Brundrett, M.C.; Abbott, L.K. 2002. Arbuscular mycorrhiza in plant communities. p. 151-193. In: Sivasithamparam, K.; Dixon, K.W.; Barrett, R.L., eds. Plant conservation and biodiversity. Kluwer Academic, Dordrecht, Netherlands.

Carneiro, R.F.V.; Cardozo Junior, F.M.; Pereira, L.F.; Araújo, A.S.F.; Silva, G.A. 2012. Arbuscular mycorrhizal fungi as indicators of the recovery of degraded areas in northeastern Brazil. Revista de Ciências Agronômicas 43: 648-657 (in Portuguese, with the abstract in English).

Cavagnaro, T.R.; Bender, S.F.; Asghari, H.R.; van der Heijden, M.G. 2015. The role of Arbuscular mycorrhizas in reducing soil nutrient loss. Trends in Plant Science 20: 283-290.

Centro de Gestão e Estudos Estratégicos [CGEE]. 2016. Land degradation neutrality: implications for Brazil. CGEE, Brasília, DF, Brazil.

Chaudhary, V. B.; Akland, K.; Johnson, N.C.; Bowker, M.A. 2020. Do soil inoculants accelerate dryland restoration? A simultaneous assessment of biocrusts and mycorrhizal fungi. Restoration Ecology 28: 115-126.

Chern, E.C.; Tsai, D.W.; Ogunseitan, O.A. 2007. Deposition of glomalin-related soil protein and sequestered toxic metals into watersheds. Environmental Science \& Technology 41: 3566-3572. 
Chi, G.; Srivastava, A.K.; Wu, Q. 2018. Exogenous easily extractable glomalin-related soil protein improves drought tolerance of trifoliate orange. Archives of Agronomy and Soil Science 64: 1341-1350.

Conversa, G.; Lazzizera, C.; Chiaravalle, A.E.; Miedico, O.; Bonasia, A.; La Rotonda, P.; Elia, A. 2019. Selenium fern application and arbuscular mycorrhizal fungi soil inoculation enhance Se content and antioxidant properties of green asparagus (Asparagus officinalis L.) spears. Scientia Horticulturae 252: 176-191.

Cornejo, P.; Seguel, A.; Aguilera, P.; Meier, S.; Larsen, J.; Borie, F. 2017. Arbuscular mycorrhizal fungi improves tolerance of agricultural plants to cope abiotic stress conditions. p. 55-80. In: Singh, D.P., ed. Plant-microbe interactions in agroecological perspectives. Vol.2. Microbial interactions and agro-ecological impacts. Springer International, Switzerland.

Diagne, N.; Ngom, M.; Djighaly, P.I.; Fall, D.; Hocher, V.; Svistoonoff, S. 2020. Roles of Arbuscular Mycorrhizal Fungi on plant growth and performance: importance in biotic and abiotic stressed regulation. Diversity 12: 370.

Douds Jr., D.D.; Nagahashi, G.; Pfeffer, P.E.; Reider, C.; Kayser, W.M. 2006. On-farm production of AM fungus inoculum in mixture of compost and vermiculite. Bioresource technology 97: 809-818.

Duc, N.H.; Csintalan, Z.; Posta, K. 2018. Arbuscular mycorrhizalfungi mitigate negative effects of combined drought and heat stress on tomato plants. Plant Physiology and Biochemistry 132: 297-307.

Elhindi, K.; Sharaf el-din, A.; Elgorban, A. 2017. The impact of arbuscular mycorrhizal fungi in mitigating salt-induced adverse effects in sweet basil (Ocimum basilicum L.) Saudi Journal of Biological Sciences 24: 170-179.

Estaún, V.; Camprubí, A.; Calvet, C.; Pinochet, J. 2003. Nursery and field response of olive trees inoculated with two arbuscular mycorrhizal fungi, Glomus intraradices and Glomus mosseae. Journal of the American Society for Horticultural Science 128: 767-775.

Food and Agriculture Organization of the United Nations [FAO]. 2015. OECD-FAO Agricultural Outlook 2015. OECD, Paris, France.

Fontes, P.F.; Alleoni, L.R.F. 2006. Electrochemical attributes and availability of nutrients, toxic elements, and heavy metals in tropical soils. Scientia Agricola 63: 589-608.

Garcia, L.; Chanda, D.; Jayachandran, K. 2019. Effect of salinity stress and microbial inoculations on glomalin production and plant growth parameters of snap bean (Phaseolus vulgaris). Agronomy 9: 545.

Gispert, M.; Emran, M.; Pardini, G.; Doni, S.; Ceccanti, B. 2013. The impact of land management and abandonment on soil enzymatic, glomalin content aggregate stability. Geoderma 202: 51-61.

Göhre, V.; Paszkowski, U. 2006. Contribution of the arbuscular mycorrhizal symbiosis to heavy metal phytoremediation. Planta 223: 1115-1122.

González-Chávez, C.; Carrillo-González, R.; Wright, S.F.; Nichols, K.A. 2004. The role of glomalin, a protein produced by arbuscular mycorrhizal fungi in sequestering potentially toxic elements. Environmental Pollution 130: 317-323.
González-Guerrero, M.; Escudero, V.; Saéz, Á.; Tejada-Jiménez, M. 2016. Transition metal transport in plants and associated endosymbionts: arbuscular mycorrhizal fungi and rhizobia. Frontiers in Plant Science 7: 1088.

Hammer, E.C.; Rillig, M.C. 2011. The influence of different stresses on glomalin levels in an arbuscular mycorrhizal fungus-salinity increases glomalin content. PLoS ONE 6: e28426.

Hart, M.; Antunes, P.; Abbott, L. 2017. Unknown risks to soil biodiversity from commercial fungal inoculants. Nature, Ecoly \& Evolution 1: 115.

He, J.D.; Chi, G.G.; Zou, Y.N.; Shu, B.; Wu, Q.S.; Srivastava, A.K.; Kuca, K. 2020. Contribution of glomalin-related soil proteins to soil organic carbon in trifoliate orange. Applied Soil Ecology 154: 103592.

Heikham, E.; Sarda, D.T.; Samta, G.; Rupam, K. 2019. Mitigation of salinity stress in plants by arbuscular mycorrhizal symbiosis: current understanding and new challenges. Frontiers in Plant Science 10: 470.

Hildebrandt, U.; Regvar, M.; Bothe, H. 2007. Arbuscular mycorrhiza and heavy metal tolerance. Phytochemistry 68: 139-146.

Hoeksema, J.D.; Chaudhary, V.B.; Gehring, C.A.; Johnson, N.C.; Karst, J.; Koide, R.T.; Pringle, A.; Zabinski, C.; Bever, J.D.; Moore, J.C.; Wilson, G.W.; Klironomos, J.N.; Umbanhowar, J. 2010. A meta-analysis of context-dependency in plant response to inoculation with mycorrhizal fungi. Ecological Letters 13: 267-407.

Hung, T.P.; Truong, L.V.; Binh, N.D.; Frutos, R.; Quiquampoix, H.; Staunton, S. 2015. Comparison of the affinity and extraction yield of trace amounts of three Cry proteins from Bacillus thuringiensisin contrasting types of soil. European Journal of Soil Science 67: 90-98.

Ijdo, M.; Cranenbrouck, S.; Declerck, S. 2011. Methods for large-scale production of AM fungi: past, present, and future. Mycorrhiza 21: 1-16.

Intergovernmental Panel on Climate Change [IPCC]. 2001. Impacts, Adaptation, and Vulnerability: Contribution of Working Group II to the Third Assessment Report of the Intergovernmental Panel on Climate Change, Climate Change 2001. IPCC, Geneva, Switzerland.

Islas, A.J.T.; Guijarro, K.H.; Eyherabide, M.; Rozas, H.R.S.; Echeverría, H.E.; Covacevich, F. 2016. Can soil properties and agricultural land use affect arbuscular mycorrhizal fungal communities indigenous from the Argentinean Pampa soil. Applied Soil Ecology 101: 47-56.

Jacobs, D.F.; Oliet, J.A.; Aronson, J.; Bolte, A.; Bullock, J.M.; Donoso, P.J. 2015. Restoring forests: what constitutes success in the twenty-first century? New Forests 46: 601-614.

Ji, L.; Tan, W.; Chen, X. 2019. Arbuscular mycorrhizal mycelial networks and glomalin-related soil protein increase soil aggregation in Calcaric Regosol under well-watered and drought stress conditions. Soil and Tillage Research 185: 1-8.

Joner, E.J.; Briones, R.; Leyval, C. 2000. Metal-binding capacity of arbuscular mycorrhizal mycelium. Plant Soil 226: 227234.

Koide, R.T.; Mosse, B. 2004. A history of research on arbuscular mycorrhiza. Mycorrhiza 14: 145-163. 
Koide, R.T.; Peoples, M.S. 2013. Behavior of Bradford-reactive substances is consistent with predictions for glomalin. Applied Soil Ecology 63: 8-14.

Koide, R.T.; Kabir, Z. 2000. Extraradical hyphae of the mycorrhizal fungus Glomus intraradices can hydrolyse organic phosphate. New Phytologist 148: 511-517.

Koziol, L.; Schultz, P.A.; House, G.L.; Bauer, J.T.; Middleton, E.L.; Bever, J.D. 2018. The plant microbiome and native plant restoration: the example of native mycorrhizal fungi. BioScience 68: 996-1006.

Krishnamoorthy, R.; Kim, K.; Kim, C.; Sa, T. 2014. Changes of arbuscular mycorrhizal traits and community structure with respect to soil salinity in a coastal reclamation land. Soil Biology and Biochemistry 72: 1-10.

Kumar, S.; Singh, A.K.; Ghosh, P. 2018. Distribution of soil organic carbon and glomalin related soil protein in reclaimed coal mineland chronosequence under tropical condition. Science of the Total Environment 625: 1341-1350.

Landrigan, P.J.; Fuller, R.; Acosta, N.J.R.; Adeyi, O.; Arnold, R.; Basu, N.; Baldé, A.B.; Zhong, M. 2018. The Lancet Commission on pollution and health. Lancet 391: 462-512.

Lehmann, E.F.; Leifheit, A.; Rillig, M.C. 2017. Mycorrhizas and soil aggregation. p. 241-262. In: Johnson, N.C.; Gehring, C.; Jansa, J. Mycorrhizal mediation of soil: fertility, structure and carbon storage. Elsevier, New York, NY, USA.

Li, T.; Hu, Y.J.; Hao, Z.P.; Li, H.; Wang, Y.S.; Chen, B.D. 2013a. First cloning and characterization of two functional aquaporin genes from an arbuscular mycorrhizal fungus Glomus intraradices. New Phytologist 197: 617-630.

Li, T.; Hu, Y.J.; Hao, Z.P.; Li, H.; Chen, B.D. 2013b. Aquaporin genes GintAQPF1 and GintAQPF2 from Glomus intraradices contribute to plant drought tolerance. Plant Signaling \& Behavior 8: e24030.

Li, J.; Meng, B.; Chai, H.; Yang, X.; Song, W.; Li, S.; Lu, A.; Zhang, T.; Sun, W. 2019. Arbuscular mycorrhizal fungi alleviate drought stress in C3 (Leymus chinensis) and C4 (Hemarthria altissima) grasses via altering antioxidant enzyme activities and photosynthesis. Frontiers in Plant Science 10: 1-12.

Li, X.; Han, S.; Luo, X.S.; Chen, W.L.; Huang, Q.Y. 2020. Arbuscular mycorrizal-like fungi and glomalin-related soil protein drive the distributions of carbon and nitrogen in a large scale. Journal of Soils and Sediments 20: 963-972.

Lin, G.; McCormack, M.L.; Guo, D. 2015. Arbuscular mycorrhizal fungal effects on plant competition and community structure. Journal of Ecology 103: 1224-1232.

Liu, H.; Wang, X.; Liang, C.; Ai, Z.; Wu, Y.; Xu, H.; Xue, S.; Liu, G. 2020. Glomalin-related soil protein affects soil aggregation and recovery of soil nutrient following natural revegetation on the Loess Plateau. Geoderma 357: 113921.

Luna, L.; Miralles, I.; Andrenelli, M.C.; Gispert, M.; Pellegrini, S.; Vignozzi, N.; Sole-Benet, A. 2016. Restoration techniques affect soil organic carbon, glomalin and aggregate stability in degraded soils of a semiarid Mediterranean region. Catena 143: 256-264.

Manaut, N.; Sanguin, H.; Ouahmane, L.; Bressan, M.; Thioulouse, J.; Baudoin, E.; Galiana, A.; Hafidi, M.; Prin, Y.; Duponnois, R. 2015. Potentialities of ecological engineering strategy based on native arbuscular mycorrhizal community for improving afforestation programs with carob trees in degraded environments. Ecological Engineering 79: 113-119.
Mardukhi, B.; Rejali, F.; Daei, G.; Ardakani, M.R.; Malakouti, M.J.; Miransari, M. 2011. Arbuscular mycorrhizas enhance nutrient uptake in different wheat genotypes at high salinity levels under field and greenhouse conditions. Comptes Rendus Biologies 334: 564-571.

Mergulhão, A.C.E.S.; Burity, H.A.; Silva, F.S.B.; Pereira, S.V.; Maia, L.C. 2010. Glomalin production and microbial activity in soils impacted by gypsum mining in a Brazilian semiarid area. American Journal of Agricultural and Biological Sciences 5: 422-429.

Middleton, E.L.; Richardson, S.; Koziol, L.; Palmer, C.E.; Yermakov, Z.; Henning, J.A.; Schultz, P.A.; Bever, J.D. 2015. Locally adapted arbuscular mycorrhizal fungi improve vigor and resistance to herbivory of native prairie plant species. Ecosphere 6: art276.

Moreira, F.M.S.; Siqueira, J.O. 2006. Soil Microbiology and Biochemistry $=$ Microbiologia e Bioquímica do Solo. 2ed. Editora UFLA, Lavras, MG, Brazil (in Portuguese).

Muchane, M.N.; Pulleman, M.M.; Vanlauwe, B.; Jefwa, J.; Kuyper, T.W. 2018. Impact of arbuscular mycorrhizal fungi and earthworms on soil aggregate stability, glomalin, and performance of pigeonpea, Cajanus cajan. Soil Research 57: 5365.

Nichols, K.A. 2008. Indirect contributions of AM fungi and soil aggregation to plant growth and protection. p. 177-194. In: Siddiqui, Z.A.; Akhtar, M.S.; Futai, K., eds. Mycorrhizae: sustainable agriculture and forestry. Springer Science, Berlin, Germany.

Nobre, C.P.; Lázaro, M.L.; Santo, M.M.E.; Pereira, M.G.; Berbara, R.L.L. 2015. Soil aggregation, glomalin and organic carbon in Araripe plateau, Ceará, Brasil. Revista Caatinga 28: 138-147 (in Portuguese, with abstract in English).

Nogueira, L.R.; Silva, C.F.; Pereira, M.G.; Gaia-Gomes, J.H.; Silva, E.M.R. 2016. Biological properties and organic matter dynamics of soil in pasture and natural regeneration areas in the Atlantic Forest biome. Revista Brasileira de Ciência do Solo 40: e0150366.

Parniske, M. 2008. Arbuscular mycorrhiza: the mother of plant root endosymbioses. Nature Reviews Genetics 6: 763-775.

Pereira, J.E.S.; Barreto-Garcia, P.A.B.; Scoriza, R.N.; Saggin Junior, O.J.; Gomes, V.S. 2018. Arbuscular mycorrhizal fungi in soils of arboreal Caatinga submitted to forest management. Revista Brasileira de Ciências Agrárias 13: e5497.

Purin, S.; Rillig, M.C. 2007. The arbuscular mycorrhizal fungal protein glomalin: limitations, progress, and a new hypothesis for its function. Pedobiologia 51: 123-130.

Purin, S.; Klauberg Filho, O. 2010. Glomalin: a new approach to understanding the biology of arbuscular mycorrhizal fungi $=$ Glomalina: nova abordagem para entendermos a biologia dos fungos micorrízicos arbusculares. p. 215-249. In: Siqueira, J.O.; Souza, F.A.; Cardoso, E.J.B.N.; Tsai, S.M., eds. Mycorrhizas: 30 years of research in Brazil = Micorrizas: 30 anos de pesquisa no Brasil. UFLA, Lavras, MG, Brazil (in Portuguese).

Querejeta J.I. 2017. Soil water retention and availability as influenced by mycorrhizal symbiosis: consequences for individual plants, communities, and ecosystems, in mycorrhizal mediation of soil. p. 299-317. In: Collins-Johnson, N.; Gehring, C.; Jansa, J., eds. Fertility, structure, and carbon storage. Elsevier, Amsterdam, Netherlands. 
Redecker, D. 2000. Specific PCR primers to identify arbuscular mycorrhizal fungi (Glomales) with in colonized roots. Mycorrhiza 10: 73-80.

Remy, W.; Taylor, T.N.; Hass, H.; Kerp, H. 1994. Four hundredmillion-year-old vesicular arbuscular mycorrizae. Proceedings of the National Academy of Sciences of the United States of America 9: 11841-11843.

Rillig, M.C.; Wright, S.F.; Nichols, K.A.; Schmidt, W.F.; Torn, M.F. 2001. Large contribution of arbuscular mycorrhizal fungi to soil carbon pools in tropical forest soils. Plant and Soil 233: 167-177.

Rillig, M.C.; Ramsey, P.W.; Morris, S.; Paul, E.A. 2003. Glomalin, an arbuscular-mycorrhizal fungal soil protein, responds to land-use change. Plant Soil 253: 293-299.

Rillig, M.C. 2004. Arbuscular mycorrhizae, glomalin, and soil aggregation. Canadian Journal of Soil Science 84: 355-363.

Rillig, M.C.; Muller, L.A.; Lehmann, A. 2017. Soil aggregates as massively concurrent evolutionary incubators. The ISME Journal 11: 1943-1948.

Sade, H.; Meriga, B.; Surapu, V.; Gadi, J.; Sunita, M.S.L.; Suravajhala, P. 2016. Toxicity and tolerance of aluminium in plants: tailoring plants to suit to acid soils. Biometals 29: 187210.

Saggin Júnior, O.J. 2019. Proposed changes to official rules and inclusion of the recommendation of mycorrhizal fungi and other microorganisms $=$ Proposta de alterações das regras oficiais e inclusão da recomendação de fungos micorrízicos e outros microrganismos. p. 19. In: Zilli, J.E.; Reis, F.B. Anais do XIX RELARE, Embrapa, Foz do Iguaçu, RS, Brazil (in Portuguese).

Santana, A.S.; Cavalcante, U.M.T.; Sampaio, E.V.D.S.B.; Costa M.L.C. 2014. Production, storage and costs of inoculum of arbuscular mycorrhizal fungi (AMF). Revista Brasileira de Botânica 37: 159-165.

Šarapatka, B.; Alvarado-Solano, D.P.; Čižmár, D. 2019. Can glomalin content be used as an indicator for erosion damage to soil and related changes in organic matter characteristics and nutrients? Catena 181: 104078.

Schüßler, A.; Walker, C. 2019. The Glomeromycota species list. The Royal Botanic Garden Kew, London, UK. Available at: http://www.amfphylogeny.com/amphylo_species.html [Accessed in Nov 19, 2020]

Seguel, A.; Cumming, J.R.; Klugh-Stewart, K.; Cornejo, P.; Borie, F. 2013. The role of arbuscular mycorrhizas in decreasing aluminium phytotoxicity in acidic soils: a review. Mycorrhiza 23: 167-183.

Seguel, A.; Cornejo, P.; Ramos, A.; Von Baer, E.; Cumming, J.; Borie, F. 2017. Phosphorus acquisition by three wheat cultivars contrasting in aluminum tolerance growing in an aluminumrich Andisol. Crop \& Pasture Science 68: 305-316.

Siddiqui, Z.A.; Pichtel, J. 2008. Mycorrhizae: An Overview. In Mycorrhizae: Sustainable Agriculture and Forestry. Springer, Berlin, Germany.

Silva, C.F.; Simões-Araújo, J.L.; Silva, E.M.R.; Pereira, M.G.; Freitas, M.S.M.; Saggin Júnior, O.J.; Martins, M.A. 2012. Arbuscular mycorrhizal fungi and glomalin-soil related protein in degraded areas and revegetated with eucalypt and wattle. Ciência Florestal 22: 749-761 (in Portuguese, with abstract in English).
Silva, C.F.; Simões-Araújo, J.L.; Silva, E.M.R.; Pereira, M.G.; Schiavo, J.A.; Freitas, M.S.M.; Saggin Júnior, O.J.; Martins, M.A. 2014. Arbuscular mycorrhizal fungi: diversity, composition and glomalin area and degraded revegetated with sesbânia. Revista Brasielira de Ciência do Solo 38: 423431 (in Portuguese, with abstract in English).

Silva, D.K.A.; Coutinho, F.P.; Escobar, I.E.C.; Souza, R.G.; Oehl, F.; Silva, G.A.; Cavalcante, U.M.T.; Maia, L.C. 2015. The community of arbuscular mycorrhizal fungi in natural and revegetated coastal areas (Atlantic Forest) in northeastern Brazil. Biodiversity and Conservation 24: 2213-2226.

Silva, C.F.; Pereira, M.G.; Santos, V.L.; Miguel, D.L.; Silva, E.M.R. 2016. Arbuscular mycorrhizal fungi: composition, lenght extraradical mycelium and glomalin in areas of Atlantic forest, Rio de Janeiro. Ciência Florestal 26: 419-433 (in Portuguese, with abstract in English).

Silva, C.F.; Pereira, M.G.; Feitosa, J.C.F.; Fonseca Junior, A.M.; Gaia-Gomes, J.H.; Menezes, C.E.G. 2017. Soil organic matter fractions, chemical attributes and aggregation under forestry and agricultural systems. Comunicata Scientiae 8: 459-468.

Silva, F. F.; Santos, T.A.; Jesus, E.C.; Chaer, G.M. 2019. Characterization of rhizobia and arbuscular mycorrhizal fungi in areas impacted by gravel mining in Brazil. Caatinga 32: 995-1004.

Silva Filho, C.P.; M.P.; Gomes, F.V.; Martins, C.; Cunha, C.S.; Lobato, M.G. 2018. Glomalin-related soil protein content in areas of degraded and revegetated caatinga in the municipality of Irauçuba. Journal of Agricultural Science 10: 302-312.

Singh, A.K.; Rai, A.; Singh, N. 2016. Effect of long-term land use systems on fractions of glomalin and soil organic carbon in the Indo-Gangetic plain. Geoderma 277: 41-50.

Singh, A.K.; Rai, A.; Pandey, V.; Singh, N. 2017. Contribution of glomalin to dissolve organic carbon under different land uses and seasonality in dry tropics. Journal of Environmental Management 192: 142-149.

Singh, A.K.; Rai, A.; Kushwaha, M.; Chauhan, P.S.; Pandey, V.; Singh, N. 2019. Tree growth rate regulate the influence of elevated $\mathrm{CO}_{2}$ on soil biochemical responses under tropical condition. Journal of Environmental Management 231: 1211-1221.

Singh, A.K.; Chen C.; Wu J.; Yang B.; Zakari S.; Jiang X.J.; Singh N.; Liu W. 2020. The role of glomalin in mitigation of multiple soil degradation problems. Critical Reviews in Environmental Science and Technology 50: 1-35.

Srivastava, P.; Giri, N.; Mandal, D. 2019. ${ }^{137}$ Cs technology for soil erosion and soil carbon redistribution. Current Science 116: 888-889.

Storer, K.; Coggan, A.; Ineson, P.; Hodge, A. 2018. Arbuscular mycorrhizal fungi reduce nitrous oxide emissions from $\mathrm{N}_{2} \mathrm{O}$ hotspots. New Phytologist 220: 1285-1295.

Smith, S.E.; Read, D.J. 2010. Mycorrhizal Symbiosis. Academic Press, New York, NY, USA.

Song, Z.; Bi, Y.; Zhang, J.; Gong, Y.; Yang, H. 2020. Arbuscular mycorrhizal fungi promote the growth of plants in the mining associated clay. Scientific Reports 10: 1-9. 
Souza, F.A.; Schlemper, T.R.; Stürmer, S.L. 2017. The importance of mycorrhizal fungi inoculation technology for sustainable vegetable production. p. 225-252. In: Lopes, C.A.; Pedroso, M.T.M. Sustainability and horticulture in Brazil: from rhetoric to practice $=$ Sustentabilidade e horticultura no Brasil: da retórica à prática. Embrapa, Brasília, DF, Brazil (in Portuguese, with abstract in English).

Soussana, J.F.; Lutfalla, S.; Ehrhardt, F.; Rosenstock, T.; Lamanna, C.; Havlík, P.; Richards, M.; Wollenberg, E.; Chotte, J.L.; Torquebiau, E.; Ciais, P.; Smith, P.; Lal, R. 2019. Matching policy and science: Rationale for the ' 4 per 1000 - soils for food security and climate initiative. Soil and Tillage Research 188: 3-15.

Spatafora, J.W.; Chang, Y.; Benny, G.L.; Lazarus, K.; Smith, M.E.; Berbee, M.L.; Bonito, G.; Corradi, N.; Grigoriev, I.V.; Gryganskyi, A. 2016. A phylum-level phylogenetic classification of zygomycete fungi based on genome-scale data. Mycologia 108: 1028-1046.

Steinberg, P.D.; Rillig, M.C. 2003. Differential decomposition of arbuscular mycorrhizal fungal hyphae and glomalin. Soil Biology and Biochemistry 35: 191-194.

Staunton, S.; Saby, N.P.A.; Arrouays, D.; Quiquampoix, H. 2020. Can soil properties and land use explain glomalin-related soil protein (GRSP) accumulation? A nationwide survey in France. Catena 193: 104620.

Tamayo, E.; Ferrol, N.; Gómez-Gallego, T.; Azcón-Aguilar, C. 2014. Genome-wide analysis of copper, iron and zinc transporters in the arbuscular mycorrhizal fungus Rhizophagus irregularis. Frontiers in Plant Science 5: 5.

Tedersoo, L.; Sánchez-Ramírez, S.; Kõljalg, U.; Bahram, M.; Döring, M.; Schigel, D.S.; May, T.; Ryberg, M.; Abarenkov, K. 2018. High-level classification of the Fungi and a tool for evolutionary ecological analyses. Fungal Diversity 90: 135-159.

United Nations [UN]. 2015. Transforming our world: the 2030 agenda for sustainable development. Available at:https://sustainabledevelopment.un.org/post2015/tr ansformingourworld [Accessed Feb 12, 2021]

Vasconcellos, R.L.F.; Bonfim, J.A.; Barreta, D.; Cardoso, E.J.B.N. 2013. Arbuscular mycorrhizal fungi and glomalin related soil protein as potential indicators of soil quality in a recuperation gradient of the Atlantic Forest in Brazil. Degradation \& Development 27: 25-334.

Wang, S.; Wu, Q.; He, X. 2015. Exogenous easily extractable glomalin-related soil protein promotes soil aggregation, relevant soil enzyme activities and plant growth in trifoliate orange. Plant, Soil and Enviroment 61: 66-71.

Wang, Q.; Lu, H.; Chen, J.; Hong, H.; Liu, J.; Li, J.; Yan, C. 2018. Spatial distribution of glomalin-related soil protein and its relationship with sediment carbon sequestration across a mangrove forest. The Science of the Total Environment 613: 548-556.

Weber, O.B.; Silva, M.C.B.; Silva, C.F. 2020. Biological and chemical attributes of soils under forest species in northeast Brazil. Journal of Forestry Research 31: 1959-1973.

Wright, S.F.; Franke-Snyder, M.; Morton, J.B.; Upadhyaya, A. 1996. Timecourse study and partial characterization of a protein on Hyphae of arbuscular mycorrhizal fungi during active colonization of roots. Plant and Soil 181: 193- 203.
Wright, S.F.; Upadhyaya, A. 1998. A survey of soils for aggregate stability and glomalin, a glycoprotein produced by hyphae of arbuscular mycorrhizal fungi. Plant and Soil 198: 97-107.

Wu, Q.S.; Xia, R.; Zou, Y.N. 2008. Improved soil structure and citrus growth after inoculation with three arbuscular mycorrhizal fungi under drought stress. European Journal of Soil Biology 44: 122-128.

Wu, Q.S.; Cao, M.Q.; Zou, Y.N.; He, X.H. 2014a. Direct and indirect effects of glomalin, mycorrhizal hyphae, and roots on aggregate stability in rhizosphere of trifoliate orange. Scientif Reports 4: 5823.

Wu, Q.S.; Huang, Y.M.; Li, Y.; Nasrullah; He, X.H. 2014 b. Contribution of arbuscular mycorrhizas to glomalin-related soil protein, soil organic carbon and aggregate stability in citrus rhizosphere. International Journal of Agriculture and Biology 16: 207-212.

Wu, Q.S.; Li, Y.; Zou, Y.N.; He, X.H. 2015. Arbuscular mycorrhiza mediates glomalin- related soil protein production and soil enzyme activities in the rhizosphere of trifoliate orange grown under different P levels. Mycorrhiza 25: 121-130.

Wu, H.; Gao, X.; Wu, M.; Zhu, Y.; Xiong, R.; Ye, S. 2020. The efficiency and risk to groundwater of constructed wetland system for domestic sewage treatment - A case study in Xiantao. Journal of Cleaner Production 277: 123384.

Wunder, S.; Bodle, R. 2019. Achieving land degradation neutrality in Germany: Implementation process and design of a land use change based indicator. Environmental Science \& Policy 92: 46-55.

Xie, X.Y.; Weng, B.S.; Zhao, S.Z.; Yan, C.L. 2013. Effects of arbuscular mycorrhizal inoculation and Cd stress on the growth and antioxidant enzyme system of Kandelia obovata. Journal of Xiamen University 52: 244-253.

Yang, Y.; He, C.; Huang, L.; Ban, Y.; Tang, M. 2017. The effects of arbuscular mycorrhizal fungi on glomalin-related soil protein distribution, aggregate stability and their relationships with soil properties at different soil depths in lead-zinc contaminated area. PLoS ONE 12: e0182264.

Zhang, B.; Li, S.; Chen, S.; Ren, T.; Yang, Z.; Zhao, H.; Liang, Y.; Han, X. 2016. Arbuscular mycorrhizal fungi regulate soil respiration and its response to precipitation change in a semiarid steppe. Scientific Reports 6: 19990.

Zhang, J.; Tang, X.L.; Zhong, S.Y.; Yin, G.C.; Gao, Y.F.; He, X.H. 2017. Recalcitrant carbon components in glomalin related soil protein facilitate soil organic carbon preservation in tropical forests. Scientific Reports 7: 2391.

Zou, Y.N.; Srivastava, A.K.; Wu, Q.S.; Huang, Y.M. 2014. Glomalin-related soil protein and water relations in mycorrhizal citrus (Citrus tangerina) during soil water deficit. Archives of Agronomy and Soil Science 60: 1103-1114. 